Article

\title{
Enzymatic Activity of Soils Forming on an Afforested Heap from an Opencast Sulphur Mine
}

\author{
Magdalena Myszura ${ }^{1}\left(\mathbb{D}\right.$, Grażyna Żukowska $^{1, *(\mathbb{D})}$, Agata Kobyłka ${ }^{2} \mathbb{D}$ and Jakub Mazurkiewicz ${ }^{3, *(\mathbb{D})}$ \\ 1 Faculty of Agrobioengineering Institute of Soil Science and Environment Shaping, University of Life Sciences \\ in Lublin, ul. St. Leszczynskiego 7, 20-069 Lublin, Poland; magdalena.myszura@up.lublin.pl \\ 2 Department of Tourism and Recreation, University of Life Sciences in Lublin, 20-950 Lublin, Poland; \\ agata.kobylka@up.lublin.pl \\ 3 Institute of Biosystems Engineering, Poznan University of Life Sciences, Wojska Polskiego 50, \\ 60-627 Poznan, Poland \\ * Correspondence: grazyna.zukowska@up.lublin.pl (G.Ż.); jakub.mazurkiewicz@up.poznan.pl (J.M.)
}

Citation: Myszura, M.; Żukowska, G.; Kobyłka, A.; Mazurkiewicz, J. Enzymatic Activity of Soils Forming on an Afforested Heap from an Opencast Sulphur Mine. Forests 2021, 12, 1469. https://doi.org/10.3390/ f12111469

Academic Editor:

Marcin Pietrzykowski

Received: 27 September 2021

Accepted: 25 October 2021

Published: 27 October 2021

Publisher's Note: MDPI stays neutral with regard to jurisdictional claims in published maps and institutional affiliations.

Copyright: (c) 2021 by the authors. Licensee MDPI, Basel, Switzerland. This article is an open access article distributed under the terms and conditions of the Creative Commons Attribution (CC BY) license (https:// creativecommons.org/licenses/by/ $4.0 /)$.

\begin{abstract}
Post-mining areas require reclamation. The main aim of reclamation is to restore the soil as a basic element of the terrestrial ecosystem. This paper presents the results of an evaluation of the enzymatic activity of soils formed on an afforested heap from an opencast sulphur mine. Six research sites were selected on the overburden heap of the Piaseczno sulphur mine, afforested 50 years ago. They differed in the type of soil in the subsoil and in the species composition of the stand. The activity of dehydrogenases, phosphatases, urease, total organic carbon, and total nitrogen was determined and statistical analysis of the obtained results showed that the activity of the evaluated enzymes in the soils formed in the reclaimed areas was significantly dependent on the type of substrate and the species composition of the plants. The activity of the evaluated enzymes was significantly positively correlated with the content of total nitrogen and the $\mathrm{C} / \mathrm{N}$ ratio, and the activity of phosphatases and urease with the total organic carbon content. Within soils developed on the same texture, the influence of stand species was revealed. In soils formed on clay, the soils under the beech stand and under the birch stand were characterized by higher activity of enzymes. The soil developing under the stands of European larch and red oak was characterized by higher enzymatic activity on weakly clayey sands. On loose sands, the activity of dehydrogenases and urease was significantly higher under acacia robinia than under hornbeam.
\end{abstract}

Keywords: post-mining area; reclamation; afforestation; soils; enzymatic activity

\section{Introduction}

The negative impact of anthropopression on the earth's surface is observed mainly in industrial, urban, communication, and agricultural areas. Strong human interference in these areas causes far-reaching deterioration of the physical, chemical, biological, and ecological properties of soils (degradation) or complete loss of use-values (devastation) [1-6].

DeLong et al. [7] indicate that soil degradation is of increasing concern to environmentalists, society, state and local authorities, and can be defined as a "global pandemic" as it is a worldwide problem. The FAO [8] defines soil degradation "... as a change in soil health resulting in a reduction in the capacity of the ecosystem to provide goods and ser-vices to beneficiaries. Degraded soils do not provide the normal goods and services of a soil in its ecosystem". Soil degradation, therefore, refers to a broad spectrum of changes in soil properties under the influence of natural or anthropogenic factors that alter their structure and quality [6].

The mining industry and fossil fuel-based energy production often create large soilless wastelands such as spoil and overburden heaps, open pits (pits), and landfills.

There are two types of mining: underground and opencast [9]. When minerals are extracted by opencast mining, 2-11 times more land is degraded than by underground 
mining [10]. Open-pit mining has the greatest impact on surrounding areas due to the relatively large amounts of material moved [11]. The mining process begins with the removal and/or destruction of vegetation and the removal of topsoil and overburden to varying degrees $[12,13]$. Overburden includes soil and rock that is removed to access deposits [14]. The removed topsoil is either stored in heaps surrounding the mines [15], stockpiled on the mine site for use in reclamation, or used elsewhere [2]. Storage of overburden on stockpiles leads to the loss of organic carbon due to exposure to heat and drying, and, in some cases, freezing and thawing as well as reduced nutrient cycling [12].

In order to reduce the negative impact of areas transformed as a result of the opencast mining of minerals (raw materials) and to restore the ecosystem functions of soils, it is necessary to reclaim and reconstruct these areas [16], a process that is also referred to as biological regeneration [17].

Ecological restoration, as defined by The Society for Ecological Restoration (2002) [18], is "the process of helping to restore an ecosystem that has been degraded, damaged, or destroyed". In the literature, the terms restoration, rehabilitation, reclamation, and remediation are often used interchangeably [19]. While rehabilitation is the repair of ecosystem processes, productivity, and services without returning to pre-disturbance conditions, remediation is the physical stabilisation of land to a non-erosive state, and restoration is the process of remediating a specific problem, thereby reversing or arresting environmental damage. In the mining context, restoration is synonymous with rehabilitation and is defined as a progression towards restoring the original ecosystem [20] or providing a new ecosystem when biotic and abiotic changes have been too extreme [21]. In other words, it is the process of remediating the effects of mining on the environment by restoring a stable land surface and then renewing vegetation or developing alternative land uses on the restored landform.

The main purpose of reclamation is to restore soil as the basic element of the terrestrial ecosystem $[22,23]$.

Soil reclamation methods can be divided into technical methods, in which the entire soil profile is restored through topsoil using organic and organic-mineral horizons that were previously removed from post-mining areas, or biological methods, which consist of introducing plant biomass through green manure [24].

Successful reclamation requires a number of measures to protect unstable slopes and restore vegetation. Vegetation plays an important role in protecting the soil surface from erosion. Plants growing on the slope reduce soil density, moderate soil $\mathrm{pH}$, increase soil organic matter (SOM), and accumulate mineral nutrients in a closed layer on the soil surface. Additionally, on a macro scale, vegetation restores the beauty and productivity of the land. For the above reasons, restoration of vegetation is a major challenge and a key indicator of reclamation success [2].

A common method of reclamation of post-industrial wastelands is their afforestation. In this remediation method, growing plants transform tilled or excavated materials into soil. The identification of optimal afforestation strategies and species composition in postindustrial areas is inextricably linked with the assessment of the adaptation of individual tree species to habitat conditions on reclaimed land and the impact of these species on the soil substrate [25-28].

There are numerous interactions between the composition of aboveground plant communities and belowground microbial communities in forest ecosystems [29] as changes in stand species composition can significantly affect the amount of organic matter entering the soil [30].

Determining the quality of soil in various anthropogenic landscapes, as well as forecasting the effects of changes in the soil environment, which are under the influence of the applied protection system or reclamation methods, is a difficult task due to the complexity and heterogeneity of this environment.

For a soil parameter to be useful as an indicator of the sustainability of land management practices, it must respond adequately to changes in management. In particular, 
"indicators should be sensitive enough to reflect the effects of management and climate on long-term changes in soil quality but should not be so sensitive that they are influenced by short-term weather patterns" [31]. Soil organisms meet this criterion because they respond sensitively to anthropogenic disturbances [32].

Soil quality is mainly shaped by the transformation of organic matter, primarily related to microorganisms and the enzymes they secrete, and the rate of biogeochemical transformations in the circulation of elements [33,34]. Soil enzymes catalyse transformations related to the processing of matter and energy in ecosystems. Enzyme activity is considered one of the more sensitive indicators of enzyme functioning, reflecting both the direction and nature of biogeochemical processes and the totality of fundamental transformations related to the biology and physicochemical properties of soils [35,36]. Measurements of enzymatic activity provide early evidence of subtle changes in the soil environment, long before changes in the chemical composition and physical properties of soils [34]; therefore, soil enzymes are considered a good indicator of soil quality due to their strong relationship with soil biology, ease of measurement, and rapid reflection of changes caused by soil use $[37,38]$.

Soil enzymes can reveal ecosystem disturbances because they are sensitive to management practices and, thus, have been used as indicators of biogeochemical cycles, organic matter (OM) degradation, and soil remediation. Therefore, they can represent soil quality, especially when combined with other physical or chemical properties [39,40].

Enzymes are directly involved in the biogeochemical cycling of carbon (dehydrogenases), nitrogen (urease and protease), and phosphorus (phosphatases) in ecosystems. Moreover, they respond markedly to stress factors, and the magnitude of change in their activity is related to the intensity of the acting factors.

Of the various enzymes, dehydrogenases are the best for determining soil microbial activity. They reflect the level of physiologically active microorganisms in the soil and, thus, provide correlative information on the biological activity and the microbial population in the soil. They also reflect the degree of organic matter decomposition and nutrient availability in the soil. Therefore, a change in dehydrogenase activity can be a reliable indicator for determining changes in soil fertility resulting from the biological oxidation of organic matter. Dehydrogenases play a role in the biological oxidation of soil organic matter by catalysing the transfer of hydrogen from organic substrates to inorganic acceptors. The activity of dehydrogenases reflects the rate of transformation occurring in the soil [41,42].

Urease activity, according to many authors, should be used as an indicator of soil quality and soil changes under the influence of use $[43,44]$. Phosphatases are enzymes that are involved in phosphorus metabolism in the soil, while urease catalyses the hydrolysis of urea to ammonia and ammonium ion [45].

The activity of soil enzymes (dehydrogenase, phosphatase, and urease) is used to assess the effects of reclamation, but the results presented most often refer to the effects 2 to 5 years after reclamation. The paper presents the results of research on the properties of enzymatic activity of soils in the reclaimed dump of the sulphur opencast mine in Piaseczno (Poland). The differences in the activity of dehydrogenase, phosphatases and urease in soils developing on a substrate of various textures (clay, sands, and loose sands) and under various stands, 50 years after planting, were assessed.

\section{Materials and Methods}

The studies were carried out on a reclaimed heap of the "Piaseczno" opencast sulphur mine. The heap is situated in the Świętokrzyskie Voivodeship, Sandomierz County, Łoniów Commune (Poland, N 50 $35^{\prime}, \mathrm{E} 21^{\circ} 47^{\prime}$ ). The area is characterised by an average annual temperature of $+8.5^{\circ} \mathrm{C}$, an average annual precipitation of $600 \mathrm{~mm}$, and a growing season of 212 days. The heap is built of Neogene clay formations (pectenic Cracowian clays), admixtures of Quaternary sandy formations, and their mixtures [46-48]. The soils formed on the examined substrates were classified as industrial and urban soil types and subtypes of soils with undeveloped profiles [49]. 
The opencast mining of sulphur deposits in Piaseczno lasted 14 years, until 1971; then, until 1980, glassy sands were extracted from under the sulphur deposits. As a result of the mining activity, a deep excavation pit was formed with an area of approx. 160 ha and a depth of up to $48 \mathrm{~m}$. The overburden heap covered an area of about 120 ha.

The studies included an assessment of the biological activity of soils developing on the reclaimed and afforested overburden heap. Six test sites (300 $\mathrm{m}^{2}$ each) were selected for the studies. The research sites were located on substrates that differed in terms of the soil texture (clay, weak clayey sand, and loose sand) and species composition of the stand (clay: (RP1) a beech (Fagus sylvatica L.) dominant stand, (RP2) a bearded birch (Betula pendula Roth) stand; weak clayey sands: (RP3) a European larch stand (Larix decidua Mill), (RP4) a red oak stand (Quercus rubra); loose sands: (RP5) a predominantly hornbeam stand (Carpinus betulus), and (RP6) an acacia robinia stand (Robinia pseudoacacia L.)) (Table 1). The study was conducted 50 years after the introduction of permanent tree planting. The basic physical and chemical properties of the soils of the study sites are presented in Table 2.

Table 1. Characteristics of research points on the outer heap of the Piaseczno mine.

\begin{tabular}{ccc}
\hline $\begin{array}{c}\text { Research } \\
\text { Point }\end{array}$ & Soil Texture & Tree stand \\
\cline { 1 - 1 } RP 1 & clay & beech dominant stand (Fagus sylvatica L.) \\
\cline { 1 - 1 } RP 2 & weak clayey sands & bearded birch stand (betula pendula roth) \\
\cline { 1 - 1 } RP 3 & sP 4 & European larch stand (larix decidua mill) \\
\cline { 1 - 1 } RP 5 & sands loose & red oak stand (Quercus rubra L.) \\
\cline { 3 - 3 } RP 6 & & $\begin{array}{c}\text { acacia robinia stand (tree stand from the upper part } \\
\text { of the slope) (Robinia pseudacacia L.) }\end{array}$ \\
\hline
\end{tabular}

Table 2. Characteristics of selected physicochemical properties. Average values. Characteristics of the soil prior to setting up the experiment.

\begin{tabular}{|c|c|c|c|c|c|}
\hline \multirow{2}{*}{$\begin{array}{c}\text { Research } \\
\text { Point }\end{array}$} & $\mathrm{pH}$ & $\mathbf{H}$ & $\mathbf{S}$ & $\mathbf{T}$ & $\mathbf{V}$ \\
\hline & (1 mol KCl) & & $\left(\mathrm{cmol}^{(+)} \cdot \mathrm{kg}^{-1}\right)$ & & $(\%)$ \\
\hline $\mathrm{RP} 1$ & $6.90 \pm 0.02$ & $2.00 \pm 0.24$ & $20.19 \pm 0.05$ & $20.19 \pm 0.06$ & $90.94 \pm 0.15$ \\
\hline RP 2 & $6.90 \pm 0.03$ & $1.93 \pm 0.13$ & $17.89 \pm 0.04$ & $19.86 \pm 0.12$ & $89.81 \pm 0.14$ \\
\hline RP 3 & $5.60 \pm 0.02$ & $5.10 \pm 0.05$ & $10.05 \pm 0.09$ & $15.30 \pm 0.03$ & $65.56 \pm 0.02$ \\
\hline $\mathrm{RP} 4$ & $5.80 \pm 0.06$ & $6.23 \pm 0.04$ & $8.54 \pm 0.03$ & $14.92 \pm 0.03$ & $57.17 \pm 0.38$ \\
\hline RP 5 & $4.80 \pm 0.09$ & $14.02 \pm 0.15$ & $4.85 \pm 0.05$ & $18.94 \pm 0.47$ & $26.94 \pm 0.20$ \\
\hline RP 6 & $4.70 \pm 0.05$ & $8.02 \pm 0.02$ & $2.95 \pm 0.03$ & $10.94 \pm 0.02$ & $25.76 \pm 0.01$ \\
\hline
\end{tabular}

Explanation: H-hydrolytic acidity; S-sum of basic cations; T-total sorption capacity; V-degree of saturation of the sorption complex with basic cations. Mean \pm standard deviation.

\subsection{Sampling for Analyses}

Soil samples were taken from 0 to $20 \mathrm{~cm}$ depth (humus horizon) according to the principles defined in ISO 18400 [50]. Soil material was collected for laboratory analyses in the autumn (October 2020) during periods of stable weather. At that time, the soil was in a state of dynamic equilibrium that kept biochemical processes within moderate intensity. Five evenly spaced points were sampled from each study plot before being mixed, and an individual averaged sample was taken for each study site. 


\subsection{Laboratory Analyses}

\subsubsection{Total Organic Carbon (TOC), Total Nitrogen (Nt), C/N Ratio}

Total organic carbon (TOC) was determined in dry soil samples by combustion using a TOC-VCSH apparatus [51] with an SSM-5000A module (Shimadzu). Total nitrogen (Nt) content was determined by the modified Kjeldahl method using a Kjeltech TM 8100 distillation unit. The $\mathrm{C} / \mathrm{N}$ ratio was calculated from the ratio of total organic carbon (TOC) and total nitrogen $(\mathrm{Nt})$. All determinations were performed in three parallel replications.

\subsubsection{Soil Enzyme Activity}

The activities of three soil enzymes, i.e., dehydrogenases, neutral phosphatase, and urease were determined in three replicates. The activity of dehydrogenases (ADh) was determined by the Thalmann method [52] using a 1\% solution of 2,3,5-triphenyltetrazolium chloride (TTC) as the substrate. Phosphatase activity (APh) was determined according to Tabatabai and Bremner [52] using 0.8\% p- nitrophenyl disodium phosphate solution as the substrate in a pH 7.0 buffer. Urease activity (AU) was determined according to Zantua and Bremner [52] using a 2.5\% urea solution as substrate. Enzyme activities were determined using a CECIL CE 2011 spectrophotometer at the following wavelengths: $\lambda=485 \mathrm{~nm}$ for dehydrogenases, $\lambda=410 \mathrm{~nm}$ for phosphatase, and $\lambda=410 \mathrm{~nm}$ for urease. Soil samples for enzymatic analyses were collected and stored according to the rules defined in the Polish PN-ISO 1998 standard [53]. All determinations were performed in three parallel repetitions.

\subsection{Statistical Analyses}

Statistical analyses were performed using the Statistica 13 program. Basic descriptive statistics were determined, namely the mean and the standard deviation, which determines the degree of variation of the results. One-way ANOVA was used to test the significance of differences in the content of individual enzymes and the values of TOC and Nt indices between individual reclamation variants. If statistically significant differences between the averages of the soil properties studied were demonstrated, Tukey's post-hoc (multiple comparisons) tests (HSD) were performed.

Two methods of numerical taxonomy (cluster analysis) were used to determine groups of reclamation variants characterised by a similarity of enzyme activity/content (dehydrogenase, phosphatase, and urease) and index values (TOC, Nt, and C/N) [54]:

- Ward's method-to determine the number of clusters (distance measure-Euclidean) based on visual analysis of the graph of distance changes in successive agglomeration stages (significant increase in agglomeration distance on the graph) and the connection tree (Ward's dendrogram);

- The k-means method-to determine the composition of clusters. The analysis of variance was also performed to determine the significance of cluster differentiation.

The basis for creating groups of reclamation variants, which are characterised by their structural similarity, was a set of normalised (standardised) diagnostic variables, denoted as nij. On the basis of the classification obtained with the k-means method, mean values of the initial variables (xij) in the obtained clusters were compared as well as internal and inter-group variances. Thus, it was possible to assess [54]:

- Internal homogeneity (homogeneity) of the clusters;

- The extent to which the obtained clusters differed from each other;

- Which sub-variables determined the differentiation of the internal structure of the reclamation variants that form the clusters.

Principal component analysis (PCA) was used to interpret the relationships between the studied variables and to search for relationships between the reclamation methods of the heap and the studied soil properties. 


\section{Results}

The process of organic matter accumulation plays a key role in the development of soils on reclaimed post-industrial sites [55]. Soil organic matter supports key ecosystem functions in soils and plays a key role in shaping soil fertility as well as being a source of energy and nutrients for soil microorganisms [56].

The results demonstrated that in soils developed on reclaimed post-industrial land, afforestation significantly increased the content of total organic carbon (TOC), determined by the type of soil material that was reclaimed and (to a much lesser extent) by the species composition of the stands (Table 3).

Table 3. Total Organic Carbon (TOC), Total Nitrogen (Nt) Content, and C/N ratio.

\begin{tabular}{cccc}
\hline \multirow{2}{*}{ Research Point (RP) } & TOC & Nt & C/N \\
\cline { 2 - 3 } & \multicolumn{2}{c}{$\mathbf{g} \cdot \mathbf{k g}^{-\mathbf{1}}$} & 15.34 \\
RP1 & $31.30 \pm 0.10^{\mathrm{e}}$ & $2.04 \pm 0.02^{\mathrm{e}}$ & 16.13 \\
RP2 & $19.84 \pm 0.03^{\mathrm{c}}$ & $1.23 \pm 0.03^{\mathrm{c}}$ & 18.21 \\
RP3 & $17.48 \pm 0.08^{\mathrm{b}}$ & $0.96 \pm 0.02^{\mathrm{b}}$ & 19.05 \\
RP4 & $20.38 \pm 0.07^{\mathrm{a}}$ & $1.07 \pm 0.02^{\mathrm{a}}$ & 18.94 \\
RP5 & $20.46 \pm 0.45^{\mathrm{a}}$ & $1.08 \pm 0.01^{\mathrm{a}}$ & 14.84 \\
RP6 & $21.67 \pm 0.06^{\mathrm{d}}$ & $1.46 \pm 0.01^{\mathrm{d}}$ & \\
\hline
\end{tabular}

Explanation: different lower case letters in the upper index indicate significant differences. Mean \pm standard deviation.

Statistical analysis (Table 3) confirmed that the highest TOC content was found in the soil under the beech stand (RP1) and that this content was significantly higher than in the soil of the remaining research points. In soils located on weak clayey sand, the TOC content was determined by the species composition of the stand. In the soil on the site of the European larch stand (RP3), the TOC content was $17.48 \mathrm{~g} \cdot \mathrm{kg}^{-1}$, while on the site with the red oak stand (RP4), an increase in TOC content to $20.38 \mathrm{~g} \cdot \mathrm{kg}^{-1}$ was recorded, which was comparable to the content in soils located on clays. Soils located on loose sands were characterised by differentiated TOC contents. On the robinia acacia stand (RP6), the TOC content was higher, amounting to $21.67 \mathrm{~g} \cdot \mathrm{kg}^{-1}$. Finally, the hornbeam stand (RP5) had a TOC content of $20.46 \mathrm{~g} \cdot \mathrm{kg}^{-1}$ and was statistically similar to that of the red oak stand (RP4) on soils developed from weak clayey sands (Table 3).

The total nitrogen content in soils developed on the external heap of the opencast sulphur mine in Piaseczno varied depending on the type of substrate on which the soil was formed and the species composition of the stand. The highest total nitrogen content was recorded in the soil formed on clay under a predominantly beech stand (RP1) and amounted to $2.04 \mathrm{~g} \cdot \mathrm{kg}^{-1}$ (Table 3). A lower total nitrogen content was characteristic in soils developed on weak clayey sand. Within these soils, statistically significant differences were found in the effect of the forest stand on Nt content (Table 3). In the soil under the larch stands (RP3), the Nt content was $0.96 \mathrm{~g} \cdot \mathrm{kg}^{-1}$, and under the red oak stands (RP4), it was $1.07 \mathrm{~g} \cdot \mathrm{kg}^{-1}$. In soils that developed on loose sands, the total nitrogen content was $1.08 \mathrm{~g} \cdot \mathrm{kg}^{-1}$ under the hornbeam stands (RP5), and $1.46 \mathrm{~g} \cdot \mathrm{kg}^{-1}$ under the acacia robinia stands (RP6). Statistically significant differences in the stands' effect on Nt content were also confirmed within these soils (Table 3).

The $\mathrm{C} / \mathrm{N}$ ratio in soils formed on the external heap of the Piaseczno mine assumed values typical for forest soils (Table 3 ). There were differences in the $\mathrm{C} / \mathrm{N}$ ratio depending on the stand species composition and smaller differences depending on the type of substrate. In soils developed on clay, the $\mathrm{C} / \mathrm{N}$ ratio was 15.34 and 16.13 under the predominantly beech stand (RP1) and red birch stand (RP2), respectively. In soils developed on weak clayey sands, the $\mathrm{C} / \mathrm{N}$ ratio was 18.21 in the larch stand (RP3), and 19.05 in the red oak stand (RP4). In soils developed on loose sands, the influence of the stand on the value of the $\mathrm{C} / \mathrm{N}$ ratio was clearly noticeable; under the hornbeam stand (RP5), the value was 18.94, while under the acacia robinia stand (RP6), the value was 14.84 (Table 3). 
The Ward cluster analysis based on TOC, Nt, and C/N, considered as indicators of forest soil quality [57], confirmed that the quality of soils formed on reclaimed heaps is affected by the type of substrate and species composition of vegetation.

Ward's method was used to determine the number of clusters. The choice of three clusters was confirmed by the plot of changes in the distance of bonds in successive agglomeration steps (Figure 1). This was the first significant increase in the agglomeration distance after a longer period, where the graph was relatively "flat". A bond distance of two in the tree diagram indicated three clusters (where the dendrogram intersected). In the k-means method, the number of clusters was assumed to be $\mathrm{k}=3$ and the maximum number of iterations was set to 10 (Figure 2).

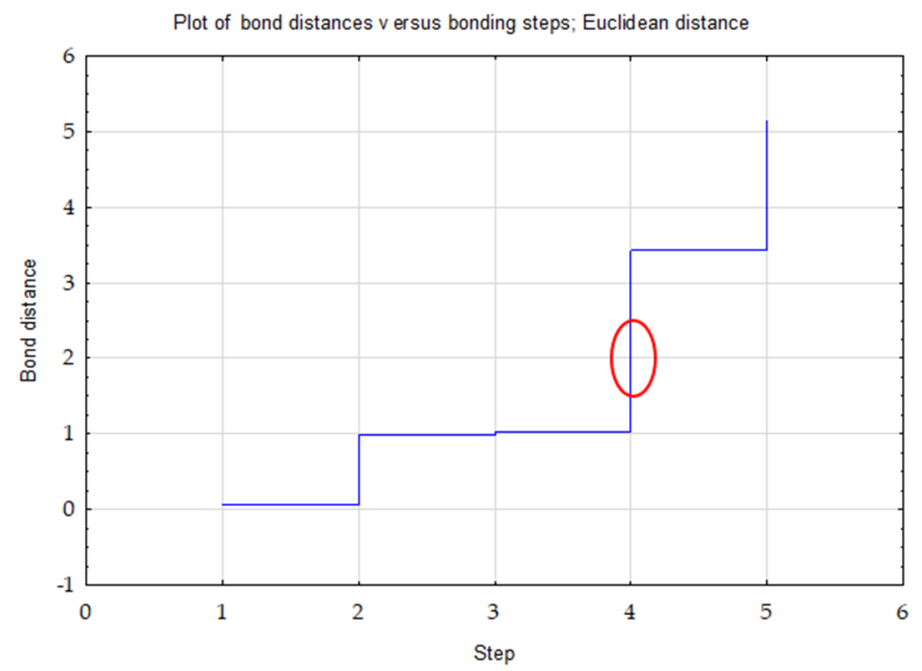

Figure 1. Graph of changes in bond distances in successive agglomeration steps for TOC, Nt and C/N.

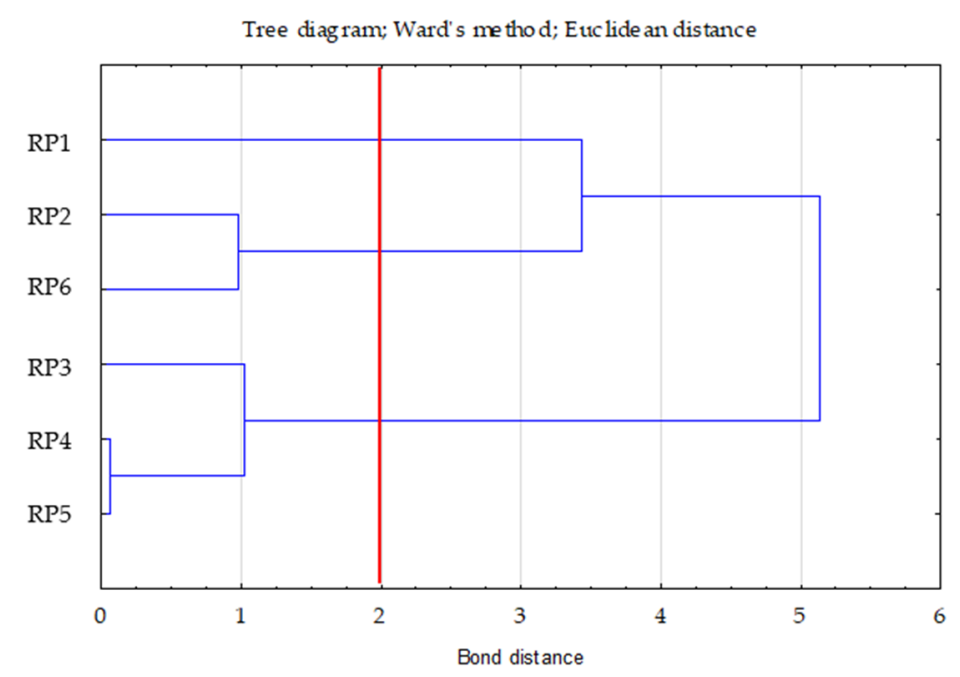

Figure 2. Tree diagram—Ward's dendogram for TOC, $\mathrm{Nt}$ and $\mathrm{C} / \mathrm{N}$.

All variables significantly differentiate $(p<0.05)$ the clusters obtained by the $k$-means method (Table 4). 
Table 4. Analysis of variance (k-means method) for TOC, Nt and C/N.

\begin{tabular}{ccccccc}
\hline Variable & between SS & df & within SS & df & F & $p^{*}$ \\
\hline TOC & 4.68 & 2 & 0.32 & 3 & 22.02 & $0.016^{*}$ \\
\hline $\mathrm{Nt}$ & 4.78 & 2 & 0.22 & 3 & 32.31 & $0.009^{*}$ \\
\hline $\mathrm{C} / \mathrm{N}$ & 4.64 & 2 & 0.36 & 3 & 19.60 & $0.019^{*}$ \\
\hline
\end{tabular}

Explanation: TOC-Total Organic Carbon; Nt-Total Nitrogen; $\mathrm{C} / \mathrm{N}-\mathrm{C} / \mathrm{N}$ ratio; SS—-sum of squares; $\mathrm{df}-$ degrees of Freedom. ${ }^{*}$ Statistically significant differences $(p<0.05)$.

The first cluster included one case (RP1-0.00 (distance from the centre of the right cluster)), the second included three (RP3-0.30; RP4-0.16; RP5-0.16), and the third included two (RP2-0.28; RP6 - 0.28). In cluster two, the RP4 and RP5 variants were very similar to each other.

In order to assess the distance between the obtained clusters, the distances between the centres of gravity of the groups were determined (Euclidean distances on the basis of standardised data) (Table 5). Clusters 1 and 2 were the most distant and, thus, dissimilar to the others (distance $=2.28$ ). Clusters 2 and 3 were the most similar (distance-1.11) (Table 5).

Table 5. Euclidean distance between clusters obtained by the k-means method for TOC, Nt and C/N.

\begin{tabular}{cccc}
\hline Clusters & $\mathbf{1}$ & $\mathbf{2}$ & $\mathbf{3}$ \\
\hline 1 & 0.00 & 2.28 & 1.16 \\
\hline 2 & & 0.00 & 1.11 \\
\hline 3 & & & 0.00 \\
\hline
\end{tabular}

Based on the cluster profiles/Cluster profile indicator, it can be seen that cluster 1 (RP1) had the highest TOC and Nt values and the lowest C/N. Cluster 2 (RP3, RP4, and RP5) had the lowest TOC and Nt values and the highest C/N. Cluster 3 (RP2 and RP6) was characterised by intermediate TOC and Nt values compared to the other two clusters and a rather low $\mathrm{C} / \mathrm{N}$ value (Table 6 ).

Table 6. Mean values of the output variables in individual clusters for TOC, Nt and C/N.

\begin{tabular}{cccc}
\hline \multirow{2}{*}{ Variable } & \multicolumn{3}{c}{ Mean Values of the Output Variables in the Clusters } \\
\cline { 2 - 4 } & Clusters 1 (RP1) & Clusters 2 (RP3, RP4, RP5) & Clusters 3 (RP2, RP6) \\
\hline TOC & 31.30 & 19.44 & 20.75 \\
\hline $\mathrm{Nt}$ & 2.04 & 1.04 & 1.34 \\
\hline $\mathrm{C} / \mathrm{N}$ & 15.34 & 18.73 & 15.49 \\
\hline
\end{tabular}

\section{Enzymatic Activity}

A reliable assessment of the quality of soils subjected to long-term anthropogenic pressure is provided by enzyme activity studies, which allow the recording of clear changes in the soil environment [34].

The activity of dehydrogenases can be used to assess soil quality, determine the influence of soil use on soil quality, and to evaluate the degree of regeneration of degraded soils [58].

In soils developed on the overburden heap of the opencast mine in Piaseczno, the dehydrogenase (ADh) activity was differentiated and assumed values ranging from 2.08 (RP5) to $25.07 \mathrm{mg} \mathrm{TPF} \cdot \mathrm{kg}^{-1} \cdot \mathrm{d}^{-1}$ (RP3) (Table 7). The type of bedrock had no effect on the activity of this enzyme (Table 7). The lowest value of dehydrogenase was found in soils developed on loose sands (RP5 and RP6). Significantly higher values were found in soils 
developed on clays (RP1 and RP2), and the highest values were found in weak clayey sands (RP3 and RP4).

Table 7. Soil enzymatic activity.

\begin{tabular}{|c|c|c|c|}
\hline \multirow{2}{*}{ Research Point (RP) } & $\mathrm{ADh}$ & $\mathrm{APh}$ & AU \\
\hline & $\mathrm{mg}$ TPF $\cdot \mathrm{kg}^{-1} \cdot \mathrm{d}^{-1}$ & $\mathrm{mmol} \mathrm{PNP} \cdot \mathrm{kg}^{-1} \cdot \mathrm{d}^{-1}$ & $\mathrm{mg} \mathrm{NH}_{4}{ }^{+} \cdot \mathrm{kg}^{-1} \cdot \mathrm{d}^{-1}$ \\
\hline $\mathrm{RP} 1$ & $14.33 \pm 0.12^{\mathrm{d}}$ & $167.40 \pm 0.10^{\mathrm{f}}$ & $28.67 \pm 0.58^{\mathrm{e}}$ \\
\hline $\mathrm{RP} 2$ & $6.44 \pm 0.04^{c}$ & $99.49 \pm 0.09^{b}$ & $11.24 \pm 0.05^{c}$ \\
\hline $\mathrm{RP} 3$ & $25.07 \pm 0.06^{\mathrm{f}}$ & $126.87 \pm 0.15^{\mathrm{d}}$ & $15.30 \pm 0.10^{\mathrm{d}}$ \\
\hline $\mathrm{RP} 4$ & $16.37 \pm 0.06^{\mathrm{e}}$ & $76.43 \pm 0.15^{\mathrm{a}}$ & $10.73 \pm 0.15^{c}$ \\
\hline RP 5 & $2.08 \pm 0.07^{\mathrm{a}}$ & $128.89 \pm 0.09^{\mathrm{e}}$ & $6.28 \pm 0.07^{\mathrm{a}}$ \\
\hline RP 6 & $6.00 \pm 0.10^{b}$ & $117.10 \pm 0.10^{c}$ & $9.59 \pm 0.09^{b}$ \\
\hline
\end{tabular}

Explanation: ADh—dehydrogenases; APh—phosphatase; AU—urease. Different lower case letters in the upper index indicate significant differences. Mean \pm standard deviation.

Phosphatases, as well as urease, are less frequently used to determine the effect of anthropopressure on soil enzyme activity; however, many authors emphasize their role in macronutrient cycles [42].

The activity of phosphatases (APh) in soils formed on the external dump was significantly different in the soils of the different study points and ranged from 76.43 to $167.40 \mathrm{mmol} \mathrm{PNP} \cdot \mathrm{kg}^{-1} \cdot \mathrm{d}^{-1}$ (Table 7). The highest phosphatase activity was found in soil developing on clay under the beech stand (RP1), while the lowest was in weak clayey sand under the red oak stand (RP4) (Table 7).

Urease activity (AU) ranged from 6.28 to $28.67 \mathrm{mg} \mathrm{NH} 4+\cdot \mathrm{kg}^{-1} \cdot \mathrm{d}^{-1}$ (Table 7). As in the case of phosphatases, the highest urease activity was found in the soil formed from clay under a predominantly beech stand (RP1). In the soil from the other research points, urease activity was significantly lower, with the lowest urease activity found in soils developed on loose sands (RP5 and RP6) (Table 7).

Ward's cluster analysis (Figure 3), based on the activity of the assessed enzymes, confirmed that the activity of soil enzymes in soils developed in reclaimed areas is significantly dependent on the type of substrate and plant species composition.

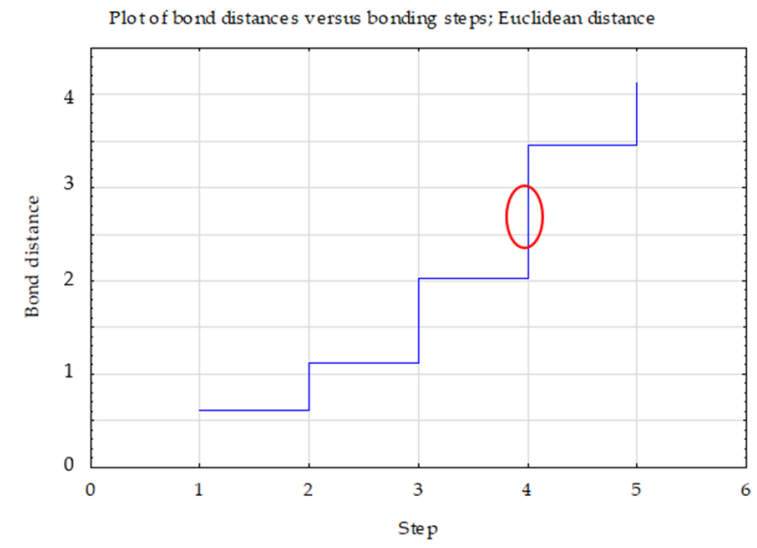

Figure 3. Graph of changes in bond distances in successive agglomeration steps for dehydrogenases, phosphatase and urease.

Three clusters were selected, the selection of which was confirmed by the graph of changes in the bond distances in successive agglomeration steps. After a longer period where the graph was relatively "flat", this was the first significant increase in agglomeration distance. A bond distance of 1.5 in the tree diagram indicated three clusters (where the 
dendrogram intersected). In the k-means method, the number of clusters was assumed to be $k=3$ and the maximum number of iterations was set at 10 (Figure 4).

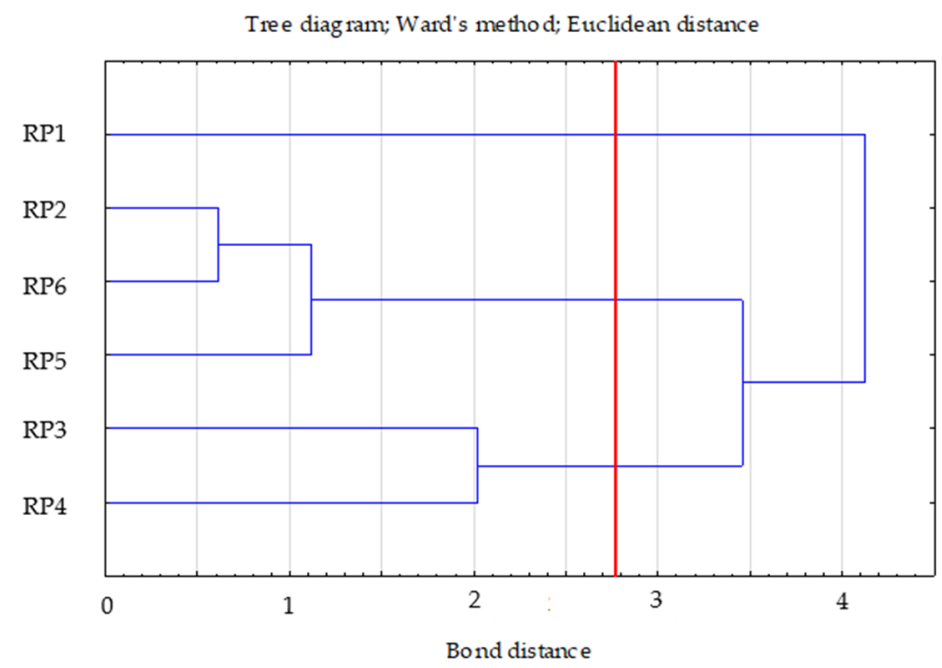

Figure 4. Tree diagram—Ward's dendogram for dehydrogenases, phosphatase and urease.

Two of the three variables significantly differentiate $(p<0.05)$ the clusters obtained by the k-means method. These are dehydrogenase and urease activities (Table 8).

Table 8. Analysis of variance (k-means method) for dehydrogenases, phosphatase and urease.

\begin{tabular}{ccccccc}
\hline Variable & between SS & df & within SS & df & F & Istotn. $\boldsymbol{p}$ \\
\hline dehydrogenases & 4.68 & 2 & 0.32 & 3 & 22.02 & $0.016^{*}$ \\
\hline phosphatase & 4.78 & 2 & 0.22 & 3 & 32.31 & $0.009^{*}$ \\
\hline urease & 4.64 & 2 & 0.36 & 3 & 19.60 & $0.019^{*}$ \\
\hline
\end{tabular}

Explanation: SS—-sum of squares; df-degrees of Freedom. * Statistically significant differences $(p<0.05)$.

The first cluster included two cases (RP3-0.58; RP4-0.58), the second included three cases (RP2-0.35; RP5-0.38; RP6-0.1), and the third included one case (RP1-0.00). In cluster two, the RP2 and RP5 variants were similar to each other. In order to assess the distance between the obtained clusters, the distances between the centres of gravity of the groups were determined (Euclidean distances on the basis of standardised data). Clusters 2 and 3 were the most distant and thus dissimilar to the others (distance $=1.85$ ). Clusters 1 and 2 were the most similar (distance-1.15) (Table 9).

Table 9. Euclidean distance between clusters obtained by the k-means method for dehydrogenases, phosphatase and urease.

\begin{tabular}{cccc}
\hline Clusters & $\mathbf{1}$ & $\mathbf{2}$ & $\mathbf{3}$ \\
\hline 1 & 0.00 & 1.15 & 1.74 \\
\hline 2 & & 0.00 & 1.85 \\
\hline 3 & & & 0.00 \\
\hline
\end{tabular}

Based on the cluster profiles, cluster 2 (RP2, RP5, and RP6) had the lowest dehydrogenase and urease values. Cluster 1 (RP3 and RP4) was characterised by the highest value of dehydrogenase, and cluster 3 (RP1) was found to have the highest value of urease (Table 10). 
Table 10. Mean values of the output variables in individual clusters for dehydrogenases, phosphatase and urease.

\begin{tabular}{cccc}
\hline \multirow{2}{*}{ Variable } & \multicolumn{3}{c}{ Mean Values of the Output Variables in the Clusters } \\
\cline { 2 - 4 } & Clusters 1 (RP3, RP4) & Clusters 2 (RP2, RP5, RP6) & Clusters 3 (RP1) \\
\hline dehydrogenases & 20.72 & 4.84 & 14.33 \\
\hline urease & 13.02 & 9.04 & 28.67 \\
\hline
\end{tabular}

Principal component analysis (PCA) has been widely used to identify the most sensitive factor explaining the significant variation between different land use/cover types [59-62].

Figure 5 shows the results of the principal component analysis (PCA). Factors 1 and 2, extracted during the analysis, explain a total of $85.07 \%$ of the variance in the analysed properties of the studied soils. Factor 1 explains $62.51 \%$ of the variability of the analysed properties and is strongly correlated with the following variables: phosphatase content, urease content, TOC, $\mathrm{Nt}$ content, and $\mathrm{C} / \mathrm{N}$ ratio. The $\mathrm{C} / \mathrm{N}$ value is negatively correlated with the other variables. TOC content and $\mathrm{Nt}$ content are highly correlated with each other as well as phosphatase and urease activity. Factor 2 explains $22.56 \%$ of the variation in the studied traits and is strongly correlated only with dehydrogenase activity, and thus, its content does not depend on the other variables, namely the soil properties.

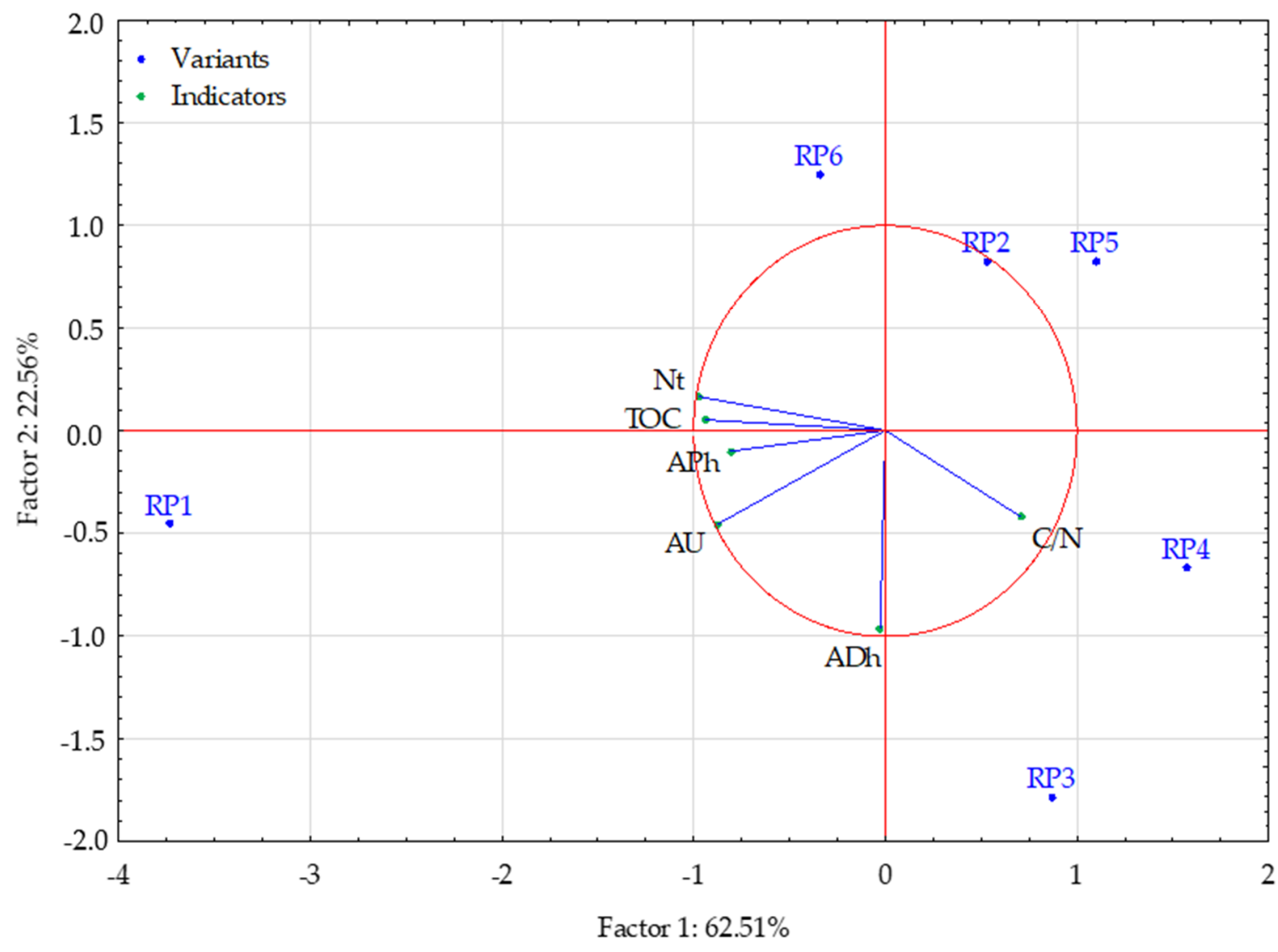

Figure 5. Projection of variables on a plane of the first and second factor. Variants: Research Point 1, 2, 3, 4, 5, 6. Indicators: TOC—Total Organic Carbon; Nt—Total Nitrogen; C/N—C/N ratio; ADh—dehydrogenases; APh—phosphatase; AU— urease. 
Test points RP2, RP3, RP4, and RP5 had lower values of TOC and Nt, and lower content of phosphatase and urease than the other two variants. Test points RP1 and RP6 had lower $\mathrm{C} / \mathrm{N}$ ratio values than the other variants. Considering the second dimension (factor), it can be seen that test points RP1, RP3, and RP4 had higher dehydrogenase activity than the other variants.

\section{Discussion}

Reclamation of post-mining areas by afforestation is a promising ecological tool to offset greenhouse gas emissions and maintain the ecological balance in post-mining ecosystems [63-66].

The study involved the evaluation of enzyme activity in soil developing on the external overburden heap of the Piaseczno opencast sulphur mine 50 years after its afforestation.

Soil enzyme activity reflects both the direction and the intensity of cyclical biogeochemical processes in the soil and is considered an important biological indicator for assessing soil fertility $[67,68]$. Soil microbial abundance and enzyme activity depend on soil properties, including soil $\mathrm{pH}$, water-air relations, and organic matter content, all of which are shaped by the type of parent rock and the course of the soil-forming process and may be subject to modification under anthropopressure [69]. Many authors indicate that the microbial composition of the soil may change depending on the diversity of the plant community growing on it, especially in the presence of the dominant species [70].

Enzymatic activity is strongly stimulated by soil organic matter (SOM) [71] and processes related to organic matter transformations are realized with the participation of soil microorganisms and their enzymes [38].

Afforestation usually results in higher plant biomass, and trees modify the quality and quantity of litter and microclimatic conditions such as humidity and temperature. Kotroczó et al. [72] showed that plants cause greater changes in soil properties through roots and secretions than through litter. Roots are a key component of the underground part of the forest ecosystem, being the primary source of SOM, which significantly affects the microbial activity of soils [73,74]. Over time, SOM input increases with stand productivity [75]. Deng and Shangguang [76] highlight the importance of tree species, soil depth, and forest age on soil $\mathrm{C}$ and $\mathrm{N}$ content.

Kara et al. [77] and Kang et al. [78] suggest that long-term afforestation can significantly increase SOM content, accumulate microbial biomass, and improve potential enzyme activity.

The results showed that the TOC content was determined by the texture of soil material that was reclaimed and by the species composition of the forest stands. The highest TOC content was characterised by the soil developing on clay under the beech stand.

In the soil developed on loamy sand, there was a significant difference in TOC content depending on the stand - under the European larch stand, it was significantly lower than under the red oak stand. On soils located on loose sands, however, the TOC content under an Acacia robinia stand, for example, was significantly higher than under a hornbeam stand. The results indicate that the content of total nitrogen, as well as TOC, differed depending on the type of substrate on which the soil was formed and the species composition of the stand.

In a forest, the species composition of the stand determines the diversity of microorganisms and their enzymatic activity [79]. The results obtained in the present study indicate that there is considerable variation in enzymatic activity within the forest soils studied. The study showed that the activity of soil enzymes in soils formed in reclaimed areas was significantly dependent on the type of substrate and plant species composition. Józefowska et al. [80] indicate that the activity of microorganisms in reclaimed soils is related to both the tree species introduced to the soil and the parent material (substrate). The relationship between microbial activity and tree species was strongest in the superficial $(0-5 \mathrm{~cm})$ soil layers. In deeper soil layers $(5-30 \mathrm{~cm})$, the microbial activity (expressed by 
MBC - microbial biomass carbon) was related to organic carbon availability, and the enzymatic activity (DHA) was related to the number of fine roots (less than $2 \mathrm{~mm}$ in diameter).

$\mathrm{ADh}$ is a very sensitive indicator of changes in soil properties and is associated with living microbial cells [44,81]. Brzezińska and Włodarczyk [82] showed a close relationship between $\mathrm{ADh}$ and organic matter content, soil fertility, soil microbial abundance, proteolytic activity, nitrification, denitrification, respiration $\left(\mathrm{CO}_{2}\right.$ release and $\mathrm{O}_{2}$ absorption), and the activity of other enzymes present in the soil environment.

The activity of dehydrogenases (ADh) varied in soils developed on the overburden heap of the opencast mine in Piaseczno. The lowest value of dehydrogenase was found in soils developed on loose sands, a significantly higher value was found in soils developed on clays, and weak clayey sands showed the highest value.

Soil enzymatic activity is strongly related to soil SOM, as it affects the energy supply for microbial growth and enzyme production. Most studies show positive correlations between enzyme activity and SOC and Nt in human-disturbed areas [83,84]. Błońska et al. [85] show that the highest activity of dehydrogenases and urease is found in forest soils, which are characterized by the greatest accumulation of soil organic matter. Soil fertility and productivity depend on the content of organic matter, which is a nutrient reservoir that is very important in the nutrient cycle [86], and which improves the physical, chemical, and biological properties of soils [87]. Bueis et al. [88], by assessing the differences in climatic parameters of the physical, chemical, and biochemical properties of soil, as well as the correlations between these parameters and the activity of the soil enzymes, revealed significant positive correlations between dehydrogenase, urease, and catalase activity and soil organic matter, including easily oxidized carbon in soils. The studies of Garcia et al. [89] and Muscolo et al. [90] show correlations between the content of soil enzymes and the content of nitrogen.

In our study, we found no significant correlation between SOC content in the substrate and dehydrogenase activity. It can be assumed that the small amount of carbon available to microorganisms in the total SOC pool may have caused this lack of correlation [91,92]. Zhang et al. [93] found that the direction of vegetation recovery was influenced by different carbon sources, which significantly affected the metabolic activity and functional diversity of microbial communities in sandy soils. In our study, within soils developing on the same substrate, significant differences in dehydrogenase activity were found depending on the stand species composition.

Soil phosphatase enzymes are produced by plant roots and microorganisms and play a key role in the cycling of phosphorus $(\mathrm{P})$, which is often a limiting element in terrestrial ecosystems. The production of these enzymes in soil is the most important biological strategy for extracting phosphate ions from organic molecules. A previously published work showed that the potential activity of phosphatases in soil is mainly determined by climatic conditions in addition to soil nitrogen $(\mathrm{N})$ and carbon [94].

The results showed that phosphatase activity in soils formed in the reclaimed overburden heap areas was significantly dependent on the type of substrate and plant species composition. The highest phosphatase activity was found on soil developing on clay under a beech stand (RP1). The lowest activity was found on weak loamy sand under a red oak stand (RP4). Within soils developing on the same substrate, the influence of stand species was revealed. In general, soils more abundant in nitrogen were characterised by higher phosphatase activity. Previous studies indicate that globally, Nt content is a good indicator of phosphatase activity [95]. High $\mathrm{N}$ content supports high phosphatase activity because phosphatase synthesis requires high amounts of $\mathrm{N}$ [95-97].

Urease is a major player in the decomposition and transformation of nitrogen in the soil ecosystem, which hydrolyses urea to ammonia or amine salt through carbon-nitrogen bonds acting on organic matter [98]. Urease directly affects the rate of soil nitrogen supply, which is usually used as an indicator of nitrogen deficit [99]. Therefore, the estimation of urease activity can help in understanding the biological mechanism of carbon and nitrogen metabolism and provide clues for assessing the quality of reclaimed soils. 
As in the case of phosphatases, the highest urease activity was found in soil made of clay, under a predominantly beech stand (RP1). In the soil of the other research points, the urease activity was significantly lower. The lowest urease activity was found in soils developed on loose sands (RP5 and RP6). Urease activity was positively correlated with TOC and Nt content, which is consistent with the study by Vahed et al. [100]. Furthermore, urease activity was correlated with the $\mathrm{C} / \mathrm{N}$ ratio. The correlation of enzymatic activity with the $\mathrm{C} / \mathrm{N}$ ratio confirms the importance of the quality of organic matter provided by plants, among others. The $\mathrm{C} / \mathrm{N}$ ratio is a long-known parameter used to assess the degree of organic matter decomposition; it was also used in the construction of indicators to assess the quality of forest soils and habitat fertility [101].

The obtained results confirm that soil enzymes-catalysts of many important soil processes, e.g., the pathway of biosynthesis and decomposition of soil humus-determine the quality and health of soils [34]. The application of enzymatic tests in forest soil monitoring, carried out on permanent observation plots, facilitates the knowledge of factors shaping the dynamics and directions of changes in the ecosystem and can provide forest management with clues for maintaining the integrity of the forest condition in endangered areas [102].

Many authors indicate that the microbial composition of the soil may change depending on the diversity of the plant community growing on the soil (especially the presence of dominant species) and the length of the growing season [70]. Differences in the microbial community and, therefore, soil enzyme activity, may also be due to differences in the number of small plant roots and their metabolic activity, and the amount and chemical composition of the litter produced by a given plant [103]. The observed changes in enzymatic activity under different tree species indicate that in the remediation of brownfield sites, it is important to match the species composition of the stand to the quality of the substrate. Tree species shape soil properties through differences in the amount and quality of organic matter that enters the soil [104,105]. In addition, tree species influence the $\mathrm{pH}$ of soils. The $\mathrm{pH}$ value has a significant influence on the activity of microorganisms in the soil; enzymes show a high sensitivity to soil $\mathrm{pH}$ [71].

\section{Conclusions}

The obtained results confirmed that soil enzymes can be used to assess the quality of reclaimed soils. The activity of the assessed enzymes in soils formed in the reclaimed areas was significantly dependent on the type of substrate and plant species composition. Significant positive correlations were found between the content of total nitrogen and $\mathrm{C} / \mathrm{N}$ ratio and the activity of the enzymes evaluated, and between the TOC content and the activity of phosphatases and urease. Within soils developed on the same substrate, the influence of stand species was revealed. The selection of the correct stand species composition to the substrate quality allows for the greatest reclamation efficiency.

Author Contributions: Conceptualization, M.M. and G.Ż.; methodology, M.M. and G.Ż.; software, A.K.; validation, A.K. and J.M.; formal analysis, M.M.; investigation, M.M. and G.Ż.; resources, J.M.; data curation, M.M. and A.K.; writing—original draft preparation, M.M.; writing-review and editing, G.Ż., A.K. and J.M.; visualization, A.K.; supervision, G.Ż. and J.M.; project administration, M.M.; funding acquisition, G.Ż. All authors have read and agreed to the published version of the manuscript.

Funding: This research received no external funding.

Institutional Review Board Statement: Not applicable.

Informed Consent Statement: Not applicable.

Data Availability Statement: Not applicable.

Conflicts of Interest: The authors declare no conflict of interest. 


\section{References}

1. Hüttl, R.F.; Weber, E. Forest ecosystem development in post-mining landscapes: A case study of the Lusatian lignite district. Naturwissenschaften 2001, 88, 322-329. [CrossRef] [PubMed]

2. Sheoran, V.; Sheoran, A.S.; Poonia, P. Soil reclamation of abandoned mine land by revegetation. Int. J. Soil Sediment Water 2010, 3, 13. [CrossRef]

3. Macdonald, S.E.; Landhausser, S.M.; Skousen, J.; Franklin, J.; Frouz, J.; Hall, S.; Jacobs, D.; Quideau, S. Forest restoration following surface mining disturbance: Challenges and solutions. New Forest 2015, 46, 703-732. [CrossRef]

4. Pietrzykowski, M. Tree species selection and reaction to mine soil reconstructed at reforested post-mine sites: Central and eastern European experiences. Ecol. Eng. 2019, 3, 100012. [CrossRef]

5. Lal, R. Restoring soil quality to mitigate soil degradation. Sustainability 2015, 7, 5875-5895. [CrossRef]

6. Gomiero, T. Soil degradation, land scarcity and food security: Reviewing a complex challenge. Sustainability $2016,8,281$. [CrossRef]

7. DeLong, C.; Cruse, R.; Wieneret, J. The Soil Degradation Paradox: Compromising Our Resources When We Need Them the Most. Sustainability 2015, 7, 866-879. [CrossRef]

8. FAO. Status of the World's Soil Resources. 2015. Available online: http://www.fao.org/3/i5228e/i5228e.pdf (accessed on 19 September 2021).

9. Northey, S.; Haque, N.; Mudd, G. Using sustainability reporting to assess the environmental footprint of copper mining. J. Clean. Prod. 2013, 40, 118-128. [CrossRef]

10. Miao, Z.; Marrs, R. Ecological restoration and land reclamation in open-cast mines in Shanxi Province, China. J. Environ. Manag. 2000, 59, 205-215. [CrossRef]

11. Lin, C.; Tong, X.; Lu, W.; Yan, L.; Wu, Y.; Nie, C.; Chu, C.; Long, J. Environmental impacts of surface mining on mined lands, affected streams and agricultural lands in the Dabaoshan Mine region, southern China. Land Degrad. Dev. 2005, 16, 463-474. [CrossRef]

12. Cooke, J.A.; Johnson, M.S. Ecological restoration of land with particular reference to the mining of metals and industrial minerals. Environ. Rev. 2002, 10, 41-71. [CrossRef]

13. Mensah, A.K. Role of revegetation in restoring fertility of degraded mined soils in Ghana: A review. Int. J. Biodivers. Conserv. 2015, 7, 57-80. [CrossRef]

14. Vela-Almeida, D.; Brooks, G.; Kosoy, N. Setting the limits to extraction: A biophysical approach to mining activities. Ecol. Econ. 2015, 119, 189-196. [CrossRef]

15. Franks, D.M.; Boger, D.V.; Côte, C.M.; Mulligan, D.R. Sustainable development principles for the disposal of mining and mineral processing wastes. Resour. Policy 2011, 36, 114-122. [CrossRef]

16. Feng, J.; Wang, Z.; Bai, L. Reading Effects of surface coal mining and land reclamation on soil properties: A review. Earth Sci. Rev. 2019, 191, 12-25. [CrossRef]

17. Wang, J.; Guo, L.; Bai, Z.; Yang, L. Using computed tomography (CT) images and multi-fractal theory to quantify the pore distribution of reconstructed soils during ecological restoration in opencast coal-mine. Ecol. Eng. 2016, 92, 148-157. [CrossRef]

18. Society for Ecological Restoration Science the SER Premieron Ecological Restoration. 2002. Available online: https:/ / www.ser.org/ (accessed on 19 September 2021).

19. Seabrook, L.; McAlpine, C.A.; Bowen, M.E. Restore, repair or reinvent: Options for sustainable landscapes in a changingclimate. Landsc. Urban Plan. 2011, 100, 407-410. [CrossRef]

20. Lima, A.T.; Mitchell, K.; O'Connell, D.W.; Verhoeven, J.; Van Cappellen, P. The legacy of surface mining: Remediation, restoration, reclamation and rehabilitation. Environ. Sci. Policy 2016, 66, 227-233. [CrossRef]

21. Hobbs, R.J.; Higgs, E.; Harris, J.A. Novel ecosystems: Implicationsfor conservation and restoration. Trends Ecol. Evol. 2009, 24, 599-605. [CrossRef]

22. Frouz, J.; Livečková, M.; Albrechtová, J.; Chroňáková, A.; Cajthamlae, T.; Pižl, V.; Háněl, L.; Starý, J.; Baldrian, P.; Lhotáková, Z.; et al. Is the effect of trees on soil properties mediated by soil fauna? A case study from post-mining sites. Forest Ecol. Manag. 2013, 309, 87-95. [CrossRef]

23. Hüttl, R.F.; Bradshaw, A. Aspect of reclamation ecology. Landsc. Urban Plan. 2000, 51, 73-74. [CrossRef]

24. Pietrzykowski, M.; Gruba, P.; Sproul, G. The effectiveness of Yellow lupine (Lupinusluteus L.) green manure cropping in sand mine cast reclamation. Ecol. Eng. 2017, 2, 72-79. [CrossRef]

25. Baumann, K.; Rumpelt, A.; Schneider, B.U.; Marschner, P.; Hüttl, R.F. Seedling biomass and element content of Pinus sylvestris and Pinus nigra grown in sandy substrates with lignite. Geoderma 2006, 136, 573-578. [CrossRef]

26. Chodak, M.; Niklińska, M. The effect of different tree species on the chemical and microbial properties of reclaimed mine soils. Biol. Fertil. Soils 2010, 46, 555-566. [CrossRef]

27. Frouz, J.; Voborilova, V.; Janusova, I.; Kodochova, S. Spontaneous establishement of late successional tree species English oak (Quercusrobur) and European beech (Fagus sylvatica) at reclaimed alder plantation and unreclaimed post mining sites. Ecol. Eng. 2015, 77, 1-8. [CrossRef]

28. Pietrzykowski, M.; Socha, J.; van Doorn, N.S. Scots pine (Pinus sylvestris L.) site index in relation to physico-chemical and biological properties in reclaimed mine soils. New Forest 2014, 46, 247-266. [CrossRef] 
29. Cline, L.C.; Zak, D.R. Soil microbial communities are shaped by plant-driven changes in resource availability during secondary succession. Ecology 2015, 96, 3374-3385. [CrossRef]

30. Hobbie, S.E.; Ogdahl, M.; Chorover, J.; Chadwick, O.A.; Oleksyn, J.; Zytkowiak, R.; Reich, P.B. Tree Species Effects on Soil Organic Matter Dynamics: The Role of Soil Cation Composition. Ecosystems 2007, 10, 999-1018. [CrossRef]

31. Doran, J.W.; Parkin, T.B. Quantitative indicators of soil quality: A minimum data set. In Methods for Assessing Soil Quality. Soil Science Society of America; Doran, J.W., Jones, A.J., Eds.; Special Publication 49; Soil Science Society of America: Madison, WI, USA, 1996; pp. 25-37. [CrossRef]

32. Wolters, V.; Schaefer, M. Effects of acid deposition on soil organisms and decomposition processes. In Effects of Acid Rain on Forest Processes; Benckiser, G., Ed.; Wiley: New York, NY, USA, 1994; pp. 83-127.

33. Schloter, M.; Dilly, O.; Munch, J.C. Indicators for evaluating soil quality. Agric. Ecosyst. Environ. 2003, 98, 255-262. [CrossRef]

34. Bielińska, E.J.; Futa, B.; Mocek-Płóciniak, A. Soil Enzymes as Bioindicators of Soil Quality and Health; Scientific Monograph; Society of Scientific Publishers "LIBROPOLIS": Lublin, Poland, 2014.

35. De la Paz Jimenez, M.; de la Horra, A.M.; Pruzzo, L.; Palma, R.M. Soil quality: A new index based on microbiological and biochemical parameters. Biol. Fertil. Soils 2002, 35, 302-306. [CrossRef]

36. Bastida, F.; Zsolnay, A.; Hernamdez, T.; Garcia, C. Past, present and future of soil quality indices: A biological perspective. Geoderma 2008, 147, 159-171. [CrossRef]

37. Trasar-Cepada, C.; Leirós, M.C.; Seoane, S.; Gil-Sotres, F. Limitations of soil enzymes as indicators of soil pollution. Soil Biol. Biochem. 2000, 32, 867-875. [CrossRef]

38. Schimel, J.P.; Bennett, J. Nitrogen mineraliztion: Challenges of a changing paradigm. Ecology 2004, 85, 591-602. [CrossRef]

39. Gelsomino, A.; Badalucco, L.; Landi, L.C.G. Soil carbon, nitrogen and phosphorus dynamics as affected by solarization alone or combined with organic amendment. Plant Soil 2006, 279, 307-325. [CrossRef]

40. Topac, F.O.; Dindar, E.; Ucaroglu, S.; Baskaya, H.S. Effect of a sulfonated azo dye and sulfanilic acid on nitrogen transformation processes in soil. J. Hazard. Mater. 2009, 170, 1006-1013. [CrossRef]

41. Fernández, D.A.; Roldán, A.; Azcón, R.; Caravaca, F.; Bååth, E. Effects of water stress, organic amendment and mycorrhizal inoculation on soil microbial community structure and activity during the establishment of two heavy metal-tolerant native plant species. Microb. Ecol. 2012, 63, 794-803. [CrossRef]

42. Kaczyńska, G.; Borowik, A.; Wyszkowska, J. Soil dehydrogenases as an indicator of contamination of the environment with petroleum products. Water Air Soil Pollut. 2015, 226, 372. [CrossRef]

43. Gil-Sotres, F.; Trasar-Cepeda, C.; Leiros, M.C.; Seoane, S. Different approaches to evaluating soil quality using biochemical properties. Soil Biol. Biochem. 2005, 37, 877-887. [CrossRef]

44. Błońska, E.; Lasota, J.; Zwydak, M. The relationship between soil properties, enzyme activity and land use. For. Res. Pap. 2017, 78, 39-44. [CrossRef]

45. Yang, Q.; Luo, K.; Li, X.M.; Wang, D.B.; Zheng, W.; Zeng, G.M.; Liu, J.J. Enhanced efficiency of biological excess sludge hydrolysis under anaerobic digestion by additional enzymes. Bioresour. Technol. 2010, 101, 2924-2930. [CrossRef]

46. Skawina, T. Characteristics of Reclamation Activities on the External Dump of the "Piaseczno" Sulfur Mine; Institute of Environmental Development and Protection: Kraków, Poland, 1974.

47. Ziemnicki, S. Reclamation of an Opencast Mine Dump (on the Example of Piaseczno). Problems of Industrialized Regions. PAN, Research Commission of Industrialized Regions; PWN: Warsaw, Poland, 1980.

48. Wegorek, T. Changes in some properties of the earth material and development of phytocoenoses in the external dump of sulfur mine as a result of target forest reclamation. Sci. Diss. AR Lub. 2003, 275, 1-140.

49. Classification of Forest Soils in Poland. Warsaw. 2000. Available online: https://www.worldcat.org/title/klasyfikacja-gleblesnych-polski/oclc/749272043 (accessed on 19 September 2021).

50. International Organization for Standardization. Soil Quality. Sampling; ISO 18400; ISO: Geneva, Switzerland, 2018; Volume 13, p. 131.

51. PN-EN 15936:2013:02. Available online: https://sklep.pkn.pl/pn-en-15936-2013-02p.html (accessed on 19 September 2021).

52. Schinner, F.; Ohlinger, R.; Kandeler, E.; Margesin, R. Methods in Soil Biology; Springer: Berlin/Heidelberg, Germany, 1995.

53. PN-ISO10381_6:1998. Available online: https://sklep.pkn.pl/pn-iso-10381-6-1998p.html (accessed on 19 September 2021).

54. Malina, A. Multidimensional analysis of the Spatial Differentiation of the Structure of the Polish Economy by Voivodship. Publishing House of the Cracow University of Economics; Wydawnictwo Akademii Ekonomicznej: Kraków, Poland, 2004; p. 162.

55. Leirós, M.C.; Gil-Sotres, F.; Ceccanti, B.; Trasar-Cepeda, M.C.; González-Sangregorio, M.V. Humification processes in reclaimed open-cast lignite mine soils. Soil Biol. Biochem. 1993, 25, 1391-1397. [CrossRef]

56. Żukowska, G.; Myszura, M.; Zdeb, M.; Pawłowska, M. Carbon Sequestration in Soil as a Sustainable Way of Greenhouse Effect Mitigation-Problems of Sustainable Development. J. Eur. Acad. Sci. Arts 2020, 15, 195-205. [CrossRef]

57. Brożek, S.; Lasota, J.; Zwydak, M. An attempt to use the forest soil trophism index for the diagnosis of lowland and upland habitats. Acta Agrar. Silvestria Ser. Silvestris 2001, 39, 35-46.

58. Paradelo, R.; Barral, M.T. Effect of moisture and dis-aggregation on the microbial activity of soil. Soil Till. Res. 2009, 104, 317-319. [CrossRef]

59. Notaro, K.A.; Medeiros, E.V.; Duda, G.P.; Silva, A.O.; Moura, P.M. Agroforestry systems, nutrients in litter and microbial activity in soils cultivated with coffee at high altitude. Sci Agric. 2014, 71, 87-95. [CrossRef] 
60. Pandey, D.; Agrawal, M.; Bohra, J.S. Effects of conventional tillage and no tillage permutations on extracellular soil enzyme activities and microbial biomass under rice cultivation. Soil Tillage Res. 2014, 136, 51-60. [CrossRef]

61. de Medeiros, E.V.; Notaro, K.A.; de Barros, J.A.; Moraes, W.S.; Silva, A.O.; Moreira, K.A. Absolute and specific enzymatic activities of sandy entisol from tropical dry forest, monoculture and intercropping areas. Soil Tillage Res. 2015, 145, 208-215. [CrossRef]

62. Moghimian, N.; Hosseini, S.M.; Kooch, Y.; Darki, B.Z. Impacts of changes in land use/cover on soil microbial and enzyme activity. Catena 2017, 157, 407-414. [CrossRef]

63. Ahirwal, J.; Kumar, A.; Pietrzykowski, M.; Maiti, S.K. Reclamation of coal mine spoil and its effect on Technosol quality and carbon sequestration: A case study from India. Environ. Sci. Pollut. Res. 2018, 25, 27992-28003. [CrossRef]

64. Ahirwal, J.; Kumar, A.; Maiti, S.K. Effect of fast-growing trees on soil properties and carbon storage in an afforested coal mine land (India). Minerals 2020, 10, 840. [CrossRef]

65. Ahirwal, J.; Maiti, S.K. Assessment of soil properties of different land uses generated due to surface coal mining activities in tropical Sal (Shorea robusta) forest, India. Catena 2016, 140, 155-163. [CrossRef]

66. Simmons, J.A.; Currie, W.S.; Eshleman, K.N.; Kuers, K.; Monteleone, S.; Negley, T.L.; Pohlad, B.R.; Thomas, C.L. Forest to reclaimed mine land use change leads to altered ecosystem structure and function. Ecol. Appl. 2008, 18, 104-118. [CrossRef]

67. Jing, C.L.; Xu, Z.C.; Zou, P.; Tang, Q.; Li, Y.Q.; You, X.W.; Zhang, C.S. Coastal halophytes alter properties and microbial community structure of the saline soils in the Yellow River Delta China. Appl. Soil Ecol. 2019, 134, 1-7. [CrossRef]

68. Yu, P.J.; Tang, X.G.; Zhang, A.C.; Fan, G.H.; Liu, S.W. Responses of soil specific enzyme activities to short-term land use conversions in a salt-affected region, northeastern China. Sci. Total Environ. 2019, 15, 687:939-945. [CrossRef]

69. Bielińska, E.J.; Mocek, A. Aktywność enzymatyczna gleby użytkowanej sadowniczo jako wskaźnik stanu środowiska wywołany stosowaniem ściółek z tworzyw sztucznych. Zesz. Probl. Post. Nauk Rol. 2003, 492, 25-37.

70. Kao-Knifn, J.T.; Balser, T.C. Elevated $\mathrm{CO}_{2}$ diferentially alters belowground plant and soil microbial community structure in reed canary grass-invaded experimental wetlands. Soil Biol. Biochem. 2007, 39, 517-525. [CrossRef]

71. Błońska, E.; Lasota, J.; Gruba, P. Effect of temperate forest tree species on soil dehydrogenase and urease activities in relation to Rother properties of soil derived from less and galciofluvial sand. Ecol. Res. 2016, 31, 655-664. [CrossRef]

72. Kotroczó, Z.; Veres, Z.; Fekete, J.; Krakomperger, Z.; Tóth, J.A.; Lajtha, K.; Tóthmérisz, B. Soil enzyme activity in response to long-term organic matter manipulation. Soil Biol. Biochem. 2014, 70, 237-243. [CrossRef]

73. Janssens, J.A.; Sampson, D.A.; Curiel-Yuste, J.; Carrara, A.; Cenlemans, R. The carbon cost of fine root turnover in a Scots pine forest. For. Ecol. Manag. 2002, 168, 231-240. [CrossRef]

74. Holubík, O.; Podrázský, V.; Vopravil, J.; Khel, T.; Remeš, J. Effect of agricultural lands afforestation and tree species composition on the soil reaction, total organic carbon and nitrogen content in the uppermost mineral soil profile. Soil Water Res. 2014, 9, 192-200. [CrossRef]

75. Kätterer, T.; Bolinder, M.A.; Andrén, O.; Kirchmann, H.; Menichetti, L. Roots contribute more to refractory soil organic matter than above-ground crop residues, as revealed by a long-term field experiment. Agric. Ecosyst. Environ. 2011, 141, 184-192. [CrossRef]

76. Deng, L.; Shangguang, Z. Afforestation drives soil carbon and nitrogen changes in China. Land Degrad. Dev. 2016, 21, 151-165. [CrossRef]

77. Kara, O.; Babur, E.; Altun, L.; Seyis, M. Effects of afforestation on microbial biomass C and respiration in eroded soils of Turkey. J. Sustain. For. 2016, 35, 385-396. [CrossRef]

78. Kang, H.; Gao, H.; Yu, W.; Yi, Y.; Wang, Y.; Ning, M. Changes in soil microbial community structure and function after afforestation depend on species and age: Case study in a subtropical alluvial Island. Sci. Total Environ. 2018, 625, 1423-1432. [CrossRef]

79. Baldrian, P. Distribution of extracellular enzymes in soils: Spatial heterogeneity and determining factors AT various scales. Soil Sci. Soc. Am. J. 2014, 78, 11-18. [CrossRef]

80. Józefowska, A.; Woś, B.; Pietrzykowski, M. Tree species and soil substrate effects on soil biota during early soil forming stages at afforested mine sites. Appl. Soil Ecol. 2016, 102, 70-79. [CrossRef]

81. Gałązka, A.; Gawryjołek, K.; Perzyński, A.; Gałązka, R.; Księżak, J. Changes in Enzymatic Activities and Microbial Communities in Soil under Long-Term Maize Monoculture and Crop Rotation. Pol. J. Environ. Stud. 2017, 26, 39-46. [CrossRef]

82. Brzezińska, M.; Włodarczyk, T. Enzymes of intracellular redox trasformations (Oxidoreductases). Acta Agrophysica Rozpr. Monogr. 2005, 3, 11-26.

83. Li, J.J.; Zheng, Y.M.; Yan, J.X.; Li, H.J.; He, J.Z. Succession of plant and soil microbial communities with restoration of abandoned land in the Loess Plateau, China. J. Soil. Sediment 2013, 13, 760-769. [CrossRef]

84. Ciarkowska, K.; Solek-Podwika, K.; Wieczorek, J. Enzyme activity as an indicator of soil-rehabilitation processes at a zinc and lead ore mining and processing area. J. Environ. Manag. 2014, 132, 250-256. [CrossRef]

85. Blonska, E.; Jarosław, L.; Zwydak, M. Relacje pomiędzy aktywnością enzymatyczną a właściwościami gleb i sposobem użytkowania. Leśne Prace Badawcze 2017, 78, 1. [CrossRef]

86. Steiner, C.; Teixeira, W.G.; Lehman, J.; Nehls, T.; de Macêdo, J.L.U.; Blum, W.E.M.; Zech, W. Long term effects of manure, charcoal and mineral fertilization on crop production and fertility on a highly weathered Central Amazonian upland soil. Plant Soil 2007, 291, 275-290. [CrossRef]

87. Bhattacharyya, R.; Prakash, V.; Kundu, S.; Srisignificantva, A.K.; Gupta, S.M. Long term effects of fertilization on carbon and nitrogen sequestration and aggregate associated carbon and nitrogen in the Indian sub-Himalayas. Nutr. Cycl. Agroecosyst. 2010, 86,1-16. [CrossRef] 
88. Bueis, T.; Turrión, M.B.; Bravo, F.; Pando, V.; Muscolo, A. Factors determining enzyme activities in soils under Pinus halepensis and Pinus sylvestris plantations in Spain: A basis for establishing sustainable forest management strategies. Ann. For. Sci. 2018, 75, 1-13. [CrossRef]

89. García, C.; Hernández, T.; Costa, F. Microbial activity in soils under Mediterranean environmental conditions. Soil Biol. Biochem. 1994, 26, 1185-1191. [CrossRef]

90. Muscolo, A.; Settineri, G.; Attina, E. Early warning indicators of changes in soil ecosystem functioning. Ecol. Indic. 2015, 48, 542-549. [CrossRef]

91. Zhang, Q.M.; Zhu, L.; Wang, J.; Xie, H.; Wang, J.; Wang, F.; Sun, F. Efects of fomesafen on soil enzyme activity, microbial population, and bacterial community composition. Environ. Monit. Assess. 2014, 186, 2801-2812. [CrossRef]

92. Fernández-Calviño, D.; Soler-Rovira, P.; Polo, A.; Díaz-Raviña, M.; Arias-Estévez, M.; Plaza, C. Enzyme activities in vineyard soils long-term treated with copper-based fungicides. Soil Biol. Biochem. 2010, 42, 2119-2127. [CrossRef]

93. Zhang, W.Y.; Yao, D.X.; Zhang, Z.G.; Yang, Q.; An, S.K. Characteristics of soil enzymes and the dominant species of repair trees in the reclamation of coal mine area. J. Coal Sci. Eng. 2013, 19, 256-261. [CrossRef]

94. Margalef, O.; Sardans, J.; Maspons, J.; Molowny-Horas, R.; Fernández-Martínez, M.; Janssens, I.A.; Peñuelas, J. The effect of global change on soil phosphatase activity. Glob. Chang. Biol. 2021, 27, 5989-6003. [CrossRef]

95. Margalef, O.; Sardans, J.; Fernández-Martínez, M.; Molowny-Horas, R.; Janssens, I.A.; Ciais, P.; Goll, D.; Richter, A.; Obersteiner, M.; Asensio, D.; et al. Global patterns of phosphatase activity in natural soils. Sci. Rep. 2017, 7, 1337. [CrossRef]

96. Olander, L.; Vitousek, P. Regulation of soil phosphatase and chitinase activity by N and P availability. Biogeochemistry 2000, 49, 175-191. [CrossRef]

97. Marklein, A.R.; Houlton, B.Z. Nitrogen inputs accelerate phosphorus cycling rates across a wide variety of terrestrial ecosystems. New Phytol. 2012, 193, 696-704. [CrossRef]

98. Li, Y.T.; Rouland, C.; Benedetti, M.; Li, F.B.; Pando, A.; Lavelle, P.; Dai, J. Microbial biomass, enzyme and mineralization activity in relation to soil organic C, N and P turnover influenced by acid metal stress. Soil Biol. Biochem. 2009, 41, 969-977. [CrossRef]

99. Dick, R.P.; Burns, R.G. A brief history of soil enzymology research. In Methods of Soil Enzymology; Dick, R.P., Ed.; Soil Science Society of America: Madison, WI, USA, 2011; pp. 1-34. [CrossRef]

100. Vahed, H.S.; Shahinrokhsar, P.; Rezaei, M. Influence of some soil properties and temperature on urease activity in Wetland Rice soils. Am. Eurasian J. Agric. Environ. Sci. 2011, 11, 310-313.

101. Ostrowska, A.; Porębska, G. Assessment of the $\mathrm{C} / \mathrm{N}$ ratio as as indicato of the decomposability of organic matter in forest soils. Ecol. Indic. 2015, 49, 104-109. [CrossRef]

102. Bielińska, E.J.; Mocek-Płóciniak, A.; Kaczmarek, Z. Indices of the eco-chemical condition of forest soils on a large-area forest fire. Pol. J. Environ. Stud. 2008, 17, 665-671.

103. Eisenhauer, N.; Lanoue, A.; Strecker, T.; Scheu, S.; Steinauer, K.; Thakur, M.P.; Mommer, L. Root biomass and exudates link plant diversity with soil bacterial and fungal biomass. Sci. Rep. 2017, 7, 44641. [CrossRef]

104. Vesterdal, L.; Schmidt, I.; Callesen, I.; Nilsson, L.; Gundersen, P. Carbon and nitrogen in forest floor and mineral soil under six common European tree species. For. Ecol. Manag. 2008, 255, 35-48. [CrossRef]

105. Guckland, A.; Jacob, M.; Flessa, H.; Thomas, F.M.; Leuschner, C. Acidity, nutrient stocks, and organic-matter content in soils of a temperate deciduous forest with different abundance of European beech (Fagus sylvatica L.). J. Plant Nutr. Soil Sci. 2009, 172, 500-511. [CrossRef] 